\title{
THE FIRST DECADE OF THE SHERMAN ACT: JUDICIAL INTERPRETATION*
}

\section{WILLIAM LETWINं}

As the first effort to control the economy at large, the Sherman antitrust law ${ }^{1}$ posed special problems for judges. Antitrust cases required more thorough and delicate analysis of economic issues than had ever been needed in resolving questions under the older branches of law. In some instances, they called for a fuller understanding of monopolistic and competitive behavior than economic theory could offer then, or can now. Controversies involving large companies and the complex structure and widespread activities of whole industries made it necessary to deal with voluminous records. But the greatest difficulty, especially pressing through the early years, was not so much to determine the facts of a case as to discover the meaning of the statute. When the difficulties of arriving at a cogent interpretation of the Sherman Act are considered, it is surprising that the courts were able, in less than a decade, to formulate the fundamental rules of law that have since governed that statute's application.

The gravest problems of interpretation arose from ambiguities in both the legal theory and language of the act. It was based on the common law, and judges generally agreed that it should be interpreted according to the common law; yet they varied widely in their opinions of what the precedents dictated. Their views could easily differ both because contradictory tendencies existed within American case law and because English common law had steadily been diverging from the more typical American precedents. The language of the act aggravated the problem of interpretation. The first section of the act declared illegal: "every contract, combination ... or conspiracy, in restraint of trade ...."2 Congress had intended by this concise formula to outlaw three sorts of agreement known to the common law, each having a proper commonlaw name: contracts in restraint of trade, combinations in restraint of trade, and conspiracies in restraint of trade. The phrase, "or commerce among the several states,"3 was appended to assert the constitutional power on which the act rested. But the entire formula, commendable for its brevity, was for that

*The second of two articles by the author, dealing with the early history of the Sherman Act. The first-concerning the Government's efforts to administer the new legislationappears in the present volume at page 464 .

†Associate Professor of Industrial History, M.I.T. School of Industrial Managament. Formerly, Research Associate in the University of Chicago Law School's Antitrust Project, under whose auspices the research for this Article was undertaken.

1. 26 Stat. 209 (1890), 15 U.S.C. §§ 1-7, 15 note (1952), as amended, 15 U.S.C. §§ 1-7 (Supp. V, 1958).

2. 26 Stat. 209 (1890), as amended, 15 U.S.C. $\$ 1$ (Supp. V, 1958).

3. Ibid. 
very reason dangerously equivocal. For one thing, it could be read as condemning "every ... conspiracy, in restraint of ... commerce among the several states," though many agreements that might be so described-for instance a malicious compact to derail a locomotive-would not have violated the common-law rules against monopoly. The word "every" also created doubts, for it could be taken to mean that the act went beyond the common law, which did not forbid "every" restraint of trade but only "unreasonable" restraints. Uncertainty about the word "every" was contagious; judges who disagreed about its significance were apt to differ next about the technical meaning of the succeeding words, "restraint of trade." All these ambiguities had somehow to be resolved before the act could be given a workable meaning.

\section{The Common-Law Doctrine of Early Cases}

The persistent difficulty of interpreting the act's common-law foundations did not arise in the first antitrust suit brought by the Government, largely because the defendants in the Jellico Mountain Coal case ${ }^{4}$ were joined in a combination of quite traditional form. A group of coal dealers and mine operators had organized the Nashville Coal Exchange, the mines agreeing to trade only with dealers in the Exchange, and the dealers in return promising to buy only from member mines; the Exchange set prices at which all members were to sell and provided penalties for any disobedience. The court did not hestitate to find that the arrangement violated the Sherman Act. Since the combination would confine the sale of coal to members and prevent them from selling cheaply, it clearly restrained trade. And since, according to the bylaws of the Exchange, the established prices would not apply to coal sold to manufacturers and steamboats "until all mines tributary to this market shall become members of the exchange, or until the exchange can control prices to govern coal used by manufacturers," the group was clearly engaged in an "attempt to monopolize" -expressly proscribed by section 2 of the act. ${ }^{6}$ The heart of the decision therefore, was reached merely by comparing the words of the statute and the words of the agreement.

In writing his opinion, Judge Key did not refer to precedents or offer much explanation, and he disposed with equal dispatch of the defendants' further arguments. They maintained, first of all, that the act was unconstitutional because, while it created criminal offenses, it authorized the Government to proceed by suits in equity, thus denying a defendant's right to trial by jury in criminal cases. They argued secondly that the agreement did not affect interstate commerce: since all the coal mines were located in Kentucky and all the dealers in Tennessee, the agreement to fix prices at the mines concerned com-

4. United States v. Jellico Mountain Coke \& Coal Co., 43 Fed. 898 (C.C.M.D. Tenn. 1890) (preliminary injunction refused), 46 Fed. 432 (C.C.M.D. Tenn. 1891) (issued).

5. 46 Fed. at 434.

6. 26 Stat. 209 (1890), as amended, 15 U.S.C. $\$ 2$ (Supp. V, 1958). 
merce within one state and the agreement to fix retail prices concerned commerce within another. Finally, they contended that the prices charged in Nashville were justified by the costs. The judge declined, however, to discuss the constitutionality of the act. He easily found the requisite effect upon interstate commerce in the transportation from the mines in Kentucky to the dealers in Tennessee; and he attached no weight to evidence about whether or how much the combination had actually raised prices of coal, for the statute condemned the "attempt to monopolize," and he held that the Exchange agreement was in itself such an attempt.

\section{The Whisky Trust Cases}

This easy conclusion was illusory. The application of the Sherman Act to particular sets of facts required, after all, a more subtle process, as the whisky trust cases of 1892 showed. The early stages of the proceedings dealt with procedural matters. The original indictment charged that certain offenses had been committed by the officers of the Distilling and Cattle Feeding Company, popularly known as a trust, but in fact a corporation chartered by the state of Illinois. These officers, having bought or leased seventy-eight distilleries that produced about three-quarters of the spirits sold in the United States, had offered certain dealers in Massachusetts rebates if they would buy only from the trust. All this was done with the clear intent to monopolize. But since the indictment, because of error or oversight, did not assert that these actions illegally affected interstate commerce or violated the Sherman Act, the court quashed it as failing to meet the requirement that defendants in criminal prosecutions be given a clear statement of the charges against them. ${ }^{7}$

\section{In re Corning}

When these defects were corrected in a new indictment, three courts in various districts were asked to decide whether the defendants could be forced to appear for trial in Boston. The judges then had to render summary judgments based on the meaning of the Sherman Act. In the first of these proceedings, In re Corning, ${ }^{8}$ Judge Ricks decided that the new indictment did not attribute any crimes to the trust. The act prohibited "restraints of trade" and "monopolizing," but the indictment did not describe any particular actions corresponding to those terms. Thus, although the indictment charged the defendants with buying up seventy distilleries, it did not assert that the defendants obliged the sellers to refrain from building other distilleries or to give up the business of distilling. And, though it alleged they offered rebates to any dealer who would buy only their goods and sell only at their prices, it did not allege that dealers were bound to those conditions by contract. Accordingly, the court decided that the indictment did not accuse the whisky trust of making any

7. United States v. Greenhut, 50 Fed. 469 (D. Mass. 1892); see Letwin, The First Decade of the Sherman Act: Early Administration, 68 YALE L.J. 464, 473 (1959).

8. 51 Fed. 205 (N.D. Ohio 1892). 
agreements of the sort traditionally recognized by the common law as contracts in restraint of trade. Nor did the indictment allege that the trust had made any agreement with independent distillers to limit output, control prices, or circumscribe markets. In short, it did not accuse them of forming with their competitors in what the common law traditionally identified as a combination in restraint of trade. Judge Ricks added that, according to the common-law meaning of "monopoly," the indictment did not support a charge on that ground: the allegation was that the trust had accumulated a great deal of property, not that it had done so in an illegal manner. Ricks therefore refused to order the defendants to stand trial in Boston. His decision was closely followed by Judge Lacombe, who heard the second case of the series, and delivered a short opinion adding only one explanatory note-the statute did not prohibit "the actual restraint of trade" but "the making of a contract in restraint of trade."9

\section{Jackson's Opinion in the Greene Case}

The doctrine implied by Ricks and Lacombe-that a business might be a monopoly in fact and not a monopoly at law if it had become the sole producer of a commodity without having done anything illegal to achieve or retain its control-was stated explicitly by Judge Jackson. In the third whisky trust proceeding, In re Greene, ${ }^{10}$ the crux of his opinion was that monopoly, as defined by the common law and by the statute (Coke and Blackstone serving as authorities on the former and Senators Edmunds and Hoar on the latter), consisted of two necessary elements: an exclusive right enjoyed by the monopolist, and restrictions imposed on others to prevent them from infringing on his privilege. Under this definition of "monopoly," the whisky trust would not monopolize even if it raised its output from three-quarters of the total liquor sold to the whole-unless in the process it restrained others. But the indictment, Jackson continued, did not allege any particular instances in which the trust had tried to curtail others in producing or selling. The rebate offered to dealers who would deal exclusively with the trust was not a restraint but an inducement; it did not bind the dealers, and there was nothing to prevent other producers from offering the same or greater rebates. ${ }^{11}$ Even if the offer were construed as a contract, it would not be a contract in general restraint of trade, of the sort judged unlawful by common-law courts, but rather a partial restraint. As such, it would be valid if it were reasonable, that is, if the restraint was not "more injurious to the public than is required to afford a fair protection to the party in whose favor it is secured."12

To support his view that the rebate agreement gave the trust only "a reasonable protection in their business," Jackson now turned to a number of commonlaw authorities, above all the recent English decision in the Mogul Steamship

9. In re Terrell, 51 Fed. 213 (C.C.S.D.N.Y. 1892).

10. 52 Fed. 104 (C.C.S.D. Ohio 1892).

11. But see note 16 infra.

12. 52 Fed. at 118. 
case. ${ }^{13}$ There, an association of shipowners had offered to give merchants in China a rebate at the end of six months if during that time they exported tea only on ships belonging to members of the association. The MIogul Steamship Company, which did not participate in the association, had maintained that its business was injured by the exclusive dealing arrangement, but had lost its suit for damages. This struck Jackson as a conclusive precedent. Although the rebate system was no doubt similar in the two cases, Jackson was nevertheless mistaken when he said that in the Mogul case "the question (almost identical with that under consideration) was presented whether the combination and arrangement adopted by the association to secure the exclusive transportation of tea trade was in any way unlawful."14 The question in the English decision was really a different one-not whether the agreement was "in any way unlawful," but, specifically, whether it did unlawful damage to the plaintiff; and, although the House of Lords denied that the association had unlawfully injured the plaintiff, it had no doubt that a common-law court would regard the association as illegal in itself and would refuse to enforce the agreement as between the parties. In the whisky trust case, on the other hand, the pertinent question was whether the defendants had violated a statute that made criminal offenses out of actions merely void at common law; and the Mogul decision-bearing only on the damage issue-did not assert that the combination was valid. Moreover, even if the similarity of the two cases had been as close as Jackson thought, the Mogul case was not an altogether convincing precedent for an American court. It had been decided two years after the Sherman Act was passed and, as a federal judge observed in an opinion delivered a few months later, the English common law on monopolies had for some years been drifting toward greater leniency while "in the United States there is a tendency to revive, with the aid of legislation, the strict rules of the common law against all forms of monopoly or engrossing." 15 And finally, it is uncertain that the rebate arrangement was so innocuous as the Mogul decision and Jackson maintained. ${ }^{16}$

13. Mogul S.S. Co. v. McGregor, Gow \& Co., [1892] A.C. 25 (1891).

14. 52 Fed. at 119 .

15. Oliver v. Gilmore, 52 Fed. 562, 566 (C.C.D. Mass. 1892) (Putnam, J.).

16. The rebate in both cases was available only to those who during some long period did all their business with one supplier. Now if a buyer has the choice of taking an equal rebate from any one of several sellers, he will regard the choice as indifferent only if each seller is equally able to supply goods whenever they are demanded. In the circumstances of the Mogul case this condition probably did not prevail, for at any moment the combine could send many more ships to the tea ports than the independent line could muster; and, consequently, the probability that an exporter would regularly get shipping space just when he needed it was greater if he dealt with the combine. If the exporter had to wait for space, he would incur storage charges or losses, which would to that extent reduce the value of a rebate. Similarly, in the whisky case, if the retailer could not be supplied as quickly or as regularly by the independent distillers as he could by the trust, the value to him of an independent's rebate-even if the independent offered the same percentage as the trust-would always be less than the value of the trust rebate, since the independent's rebate would have to be discounted for the possibility of lost sales 
In arriving at his decision, Jackson rejected the main point of the Government's pleadings, which was that the trust violated the act by its mere existence, for, though in form a single corporation, it was in fact a combination to set prices and regulate the output of what had once been seventy competing firms. He conceded that the arrangement might evidence an intent to monopolize, but the intent itself-even if accompanied by actual pre-eminence in the industry as well as by any incidental power that the trust might derive from its great size-was not illegal, and would only become so if the trust tried to realize the intent by, for instance, imposing restraints on others. Supplementing this fundamental argument, he suggested a constitutional consideration, that the federal government could not regulate the property of a corporation created by a state. ${ }^{17} \mathrm{He}$ contended also that, since the trust was formed before the act was passed, to construe its formation as illegal would be to give the act an $e x$ post facto effect. ${ }^{18}$ (One might have thought, however, that to continue a combination would be an illegal act even if to form it was not.)

\section{Further Applications of Jackson's Rationale}

Jackson's theory of the case reflected a widespread economic attitude of optimistic confidence in the natural working of competition, and rested on the belief that monopolies cannot maintain themselves simply by virtue of their economic position. This reasoning assumes that a monopoly cannot drive out competitors through such measures as price-cutting, exclusive dealing arrangements, and price discrimination. He was convinced that independent producers could as easily destroy a monopoly by using these techniques, for, he said, nothing prevented the whisky trust's competitors from offering larger rebates. If the state did not create or protect monopolies, and if it refused to enforce the restrictive agreements by which monopolies seek to protect themselves, enough competitors, actual or potential, would always be available to destroy the monopoly or limit its power to set prices. This belief led him to interpret the Sherman Act as an attempt to prohibit only those methods by which monopolies could hope to survive in the face of competition and disposed him to judge that, because it did not restrict its competitors, the whisky trust could not be violating the act. Since Jackson's view was immediately accepted as authoritative, it exercised a decisive influence for several years.

\section{The Nelson Case}

Indeed, in the next antitrust case, United States $v$. Nelson, ${ }^{19}$ Jackson's doctrine that there could be no monopolizing without restraining was carried

and extra storage charges. Jackson's argument that the independents could offer a larger rebate than the trust paid does not meet the basic problem, since it merely suggests that the independents could, if they chose, put themselves at the disadvantage of incurring greater costs than the trust, and to that extent reduce their chances of surviving the competition. [This analysis is based on suggestions by Professor Aaron Director.]

17. 52 Fed. at 112-13.

18. $I d$. at 112 .

19. 52 Fed. 646 (D. Minn. 1892). 
to even greater lengths. In a short opinion, Judge Nelson sustained the demurrer of a group of lumber merchants indicted for combining to raise prices, though he said nothing more about the merits of the case than that the defendants could not really raise the prices as they intended. He was convinced on general principles that "competition is not stifled by such an agreement, and other dealers would soon force the parties to the agreement to sell at the market price, or a reasonable price, at least."20 This observation, as far as the judge was concerned, disposed of any need to differentiate the case before him from contrary common-law precedents or from the facts of the Jellico Mountain Coal case. He simply overlooked the conflict between his view-that an attempt to raise prices was not illegal if unsuccessful-and the opinion of Judge Key in the Jellico decision-that the Sherman Act prohibited the attempt whether successful or not. Moreover, although he was following Jackson, he did not see that the facts in his case were different in one crucial respect from those in the whisky trust proceedings. There, the combining firms had become the property of a single corporation, and precedents provided a basis for deciding, as Jackson did, that the parts of any single firm, no matter how large the whole. might act in concert without constituting a combination. In contrast, the $N$ clson combination was made up of independent firms and, although their agreement might not be restraining anyone else, it was unquestionably restraining them.

\section{The Patterson Decision}

The outlines of Jackson's doctrine were followed again-this time to the detriment of the defendants-in a case heard shortly afterward, United States v. Patterson. ${ }^{21}$ Judge Putnam, in upholding the major portion of an indictment against officers of the cash register trust, seemed most impressed by the coercive methods which the trust had used to restrain trade. It had attempted to intimidate its competitors by beating or bribing their employees, employing spies, inducing breach of contract, threatening suits for patent infringement, and so forth. ${ }^{22}$ The mere fact that the trust had come to control much of the cash register business or even that it deliberately intended to control all of the business did not in itself violate the act, but since, in addition, the trust had used violence, it could be guilty of monopolizing. Violence, Putnam said, was equivalent to restrictive legal arrangements, might indeed be used to impose them on competitors, and was therefore an unlawful attempt to exclude competition. ${ }^{23}$

The Patterson decision illustrated the strength of Jackson's rationale. Those who asserted that competition would automatically destroy pacific monopolies, though probably correct in fact, were denying that the act should be used to hasten the automatic decay or that Congress had intended it to be used for
20. Id. at 647 .
21. 55 Fed. 605 (C.C.D. Mass. 1893).
22. Id. at 606 .
23. Id. at 641 . 
that purpose. But as the Patterson decision showed, by adopting this position, they were not rendering the act impotent. On the contrary, they insisted that the act prohibited any attempt to impede the process of competition whether by violent or contractual methods. This rule, as stated most fully by Jackson and followed in most cases before 1893, directed the attention of judges to overt acts, and thereby established a clear criterion of illegality. If it narrowed the scope of the act, it defined that scope precisely. The criterion it established -later expressed in the dictum, "size alone is not a violation of the act"slowly evolved into a principle that has since been used in interpreting antitrust law: control of an industry is not unlawful even though it gives the defendant power to do harm; what the act prohibits is the abuse of that power by the actual doing of harm.

\section{The Trans-Missouri Case}

Some judges went much further than Jackson and assumed not only that enough competition would naturally exist to counteract monopolies, but that in some industries there might at times be too much competition. And, while Jackson believed that the common law did not invalidate peaceful combinations, and that the law in general need not, these other judges believed that the law positively endorsed combinations whose sole purpose was to do away with excessive competition. Their view was clearly demonstrated in the first two trials of the Trans-Missouri Freight Association case. ${ }^{24}$ The defendants were a number of railroads which had joined together to fix uniform rates and terms for freight carriage. They had established a scheme whereby an association member could deviate from the established rates only by following an elaborate, time-consuming procedure, obviously designed to make him keenly aware of his colleagues' displeasure. This arrangement, said District Judge Riner (who decided the case on its first hearing), contained not a "single element of monopoly" because the defendants had no exclusive right to carry freight by rail. ${ }^{25}$ On the other hand, the agreement was certainly a contract in restraint of trade. But an extensive review of the precedents convinced Riner that such contracts were void only if the restrictions they imposed were unnecessarily broad and "publicly oppressive."20 In other words, the common law did not aim to preserve competition as such but only a desirable amount of competition. "Undoubtedly all contracts which have a direct tendency to prevent healthy competition are detrimental to the public, and, therefore, to be condemned; but when contracts go to the extent only of preventing unhealthy competition, and yet at the same time furnish the public with adequate facilities at fixed and reasonable prices, and are made only for the purpose of averting personal ruin, the contract is lawful." 27 The difficulty of determining whether the public enjoyed "adequate

24. United States v. Trans-Missouri Freight Ass'n, 53 Fed. 440 (C.C.D. Kan. 1892), aff'd, 58 Fed. 58 (Sth Cir. 1893), rev'd, 166 U.S. 290 (1897).

25. 53 Fed. at $452-53$.

26. Id. at 451 .

27. Ibid. 
facilities" at "reasonable prices" did not arise, for the framing of the issue on the pleadings required Riner to assume the truth of the defendants' assertions, and they had said that the combination was formed in order to maintain "just and reasonable rates." ${ }^{28} \mathrm{He}$ concluded that the restraint was reasonable, and that it benefited the public by eliminating excessive competition among the railroads and thus contributing to their prosperity.

This opinion might seem to have depended on an appraisal of economic order very different from Jackson's, and it did for the first time introduce into antitrust law a precedent expressing some doubt as to the unlimited merits of competition. Yet, in a broader sense, Riner and Jackson were at one, for each felt that a judge obliged by statute to follow the common law might approve an arrangement whose effect, or at least immediate effect, was to reduce competition. No doubt, there was authority in common-law cases for Riner's decision, since courts had often indicated that they would approve railroad pools designed to eliminate "ruinous" competition. ${ }^{29}$ There could be no doubt, moreover, that Riner based his decision in part on the fact that the contracting parties were railroads, for, in closing his opinion, he held that the Sherman Act did not apply to these defendants in any event because they were already regulated by the Interstate Commerce Act. ${ }^{30}$

The Eighth Circuit Court of Appeals, which reviewed the Trans-Missouri case a year later, affirmed on substantially the same principles. ${ }^{31}$ The appellate court held that, as the defendants were not joined in a monopoly of necessities or a pool, their association was not prima facie illegal. It was a combination, and as such was lawful or unlawful by common-law criteria, depending on whether it merely "regulated" or actually "suppressed" competition, that is, on whether it was "reasonable." 32 Moreover, another standard reinforced the common-law conclusion. Conceding that the Association "checked" competition among the member railroads and had been formed for this sole purpose, the court went on to maintain that Congress, in passing the Interstate Commerce Act, had itself adopted the policy of reducing competition among railroads, and that railroads which did for themselves what the law proposed to do for them could not be convicted of acting contrary to public policy. ${ }^{33}$ The only question left to decide was whether the defendants had gone too far in executing a plan that

28. Ibid.

29. Manchester \& L.R.R. v. Concord R.R., 66 N.H. 100, 20 Atl. 383 (1890); see Chicago, St. L. \& N.O.R.R. v. Pullman So. Car Co., 139 U.S. 79 (1891); Wiggins Ferry Co. v. Chicago \& A.R.R., 73 Mo. 389 (1881); Dewey, The Common-Law Backgroutd of Antitrust Policy, 41 VA. L. Rev. 759, 782-83 (1955), and cases cited therein.

30. 52 Fed. at $454-56$. Section 407 of the Transportation Act of 1920 , amending $\S$ $5(8)$ of the Interstate Commerce Act, expressly exempted railroads from the antitrust laws. 41 Stat. 456,482 (1920), as amended, 62 Stat. 472,473 (1948), 49 U.S.C. $\$ 5 b(9)$ (1952).

31. United States v. Trans-Missouri Freight Ass'n, 58 Fed. 58 (8th Cir. 1893), rcv'd, 166 U.S. 290 (1897).

32. 58 Fed. at 69,73 ,

33. Id. at 74-77. 
was unexceptionable in itself. On examining the agreement, the court determined that it would not necessarily or probably "suppress" competition. Nor did the evidence establish that the defendants had in fact charged unreasonable rates. The court accordingly upheld Judge Riner's opinion that a railroad combination was reasonable and legal if it charged "reasonable" prices.

In 1896, when District Judge Wheeler dismissed a bill brought against a similar arrangement in the Joint Traffic Association case, ${ }^{34}$ he too set forth as the ultimate test of a railroad combination's legality whether it charged "reasonable" prices.

The effect of these very early antitrust decisions, then, was to establish the doctrine that the Sherman Act should be interpreted according to the common law, and the common-law rule most often invoked was that combinations were illegal only if they restrained trade unreasonably, that is, by using restrictive agreements or physical coercion, or by excessively raising prices.

\section{The Broader Interpretation of the Act in the Labor Union Cases}

The judges who heard early labor cases arising under the Sherman Act could not so easily find a common-law tradition to guide them. It was clear, despite what the common-law rules had once been, that, since early in the nineteenth century, the cases had ceased to classify unions as unlawful combinations in themselves. And, after the decision of Commonwealth $v$. Hunt in 1842,35 strikes were no longer regarded as illegal, provided they were intended to force the strikers' own employer to raise wages and were conducted peaceably. The mere establishment of unions and the organizing of an uneventful strike therefore appeared permissible under the Sherman Act if common-law rules were to be followed. The status of other union activities was more doubtful.

\section{The First Labor Antitrust Case}

The nature of the problem became apparent in the first antitrust case involving a union, United States v. Workingmen's Amalgamated Council. ${ }^{36}$ The defendants were conducting a general strike in New Orleans. The Government sought to end it, and District Judge Billings issued a temporary injunction on the ground that the strike violated the act. While conceding that Congress had been moved to enact the antitrust laws by "the evils of massed capital," he nevertheless held that, in the course of debate, "the subject had so broadened in the minds of the legislators" that they had decided to interdict "every contract or combination in the form of trust, or otherwise in restraint of trade or commerce," whether organized by businessmen or by laborers. ${ }^{37}$ Was this

34. United States v. Joint Traffic Ass'n, 76 Fed. 895 (C.C.S.D.N.Y. 1896), aff'd mem., 89 Fed. 1020 (2d Cir. 1897), rev'd, 171 U.S. 505 (1898).

35. 45 Mass. (4 Met.) 111 (1842).

36. 54 Fed. 994 (C.C.E.D. La.), aff'd, 57 Fed. 85 (5th Cir. 1893).

37. 54 Fed. at 996. 
strike illicitly "in restraint of trade"? Billings conceded that unions as such were lawful and, in effect, accepted the defendants' argument that ordinary strikes were lawful as well. ${ }^{38}$ And he did not maintain that the Council's strike would be illegal at common law, though he did point out, in summarizing the evidence, that the strikers had practiced violence and intimidation. ${ }^{39}$ Therefore, in order to show that the strike violated the Sherman Act, Billings had to conclude that, despite the common law, it was a "combination ... in restraint of trade." The only authority he offered was a somewhat remote New York precedent, People v. Fisher. ${ }^{40}$ Decided in 1835 , it was one of the last to forbid an ordinary strike involving no violence. Moreover, the particular remark quoted by Billings as authoritative was obiter dictum. Chief Justice Savage of New York had written that certain strikes, including general strikes, "would be productive of derangement and confusion, which certainly must be considered 'injurious to trade'." 41 The justice wrote "would be" rather than "are" because his remark was an afterthought that did not concern the events of his case, a peaceful strike of shoemakers. Finally, even this aged dictum was not very suitable for Billings' purposes. The quotation marks that had surrounded "injurious to trade" when Savage used the words, and that vanished when Billings repeated them, ${ }^{42}$ were no mere affectation, for the words occurred in the New York statute invoked in People v. Fisher, a statute that outlawed conspiracies "injurious to trade." 43 But Billings quietly overlooked all these defects in his precedent and reasoned that, since a general strike had once been said to "injure" trade, it must now be judged to "restrain" trade. Forgetting also that the words "restraint of trade" in the Sherman Act were intended to be given their common-law, rather than their literal, meaning, he was able to deduce that the New Orleans general strike violated the act. It would not, perhaps, have been much more difficult to reason that a gang of train-robbers would violate the antitrust statute, for they too would be a combination and would "restrain trade" if they halted a train.

The Circuit Court of Appeals for the Fifth Circuit soon affirmed or appeared to affirm Billings' decision. ${ }^{44}$ In fact, the court upheld only the technical propriety of the proceedings and said little about the substance of the opinion, since the lower court had not yet concluded its hearings: "On this appeal from an interlocutory order, which we affirm, we deem it unnecessary to anticipate the further progress and final hearing of this case by an expression of our views as to the full scope and sound construction of this recent and important statute."45 But the lower court never held final hearings, and the original decision stood as the

38. Id. at 999 .

39. Id. at 1000 .

40. 14 Wend. 9 (N.Y. Sup. Ct. Jud. 1835).

41. Id. at 19.

42. 54 Fed. at 1000 .

43. 14 Wend. at 14.

44. Workingmen's Amalgamated Council v. United States, 57 Fed. 85 (5th Cir. 1893).

45. Id. at 86 . 
only substantial precedent in the field when the Pullman strike cases came before the courts a year later. The judges in those cases relied on Billings' opinion and regarded the decision of the court of appeals as greatly enhancing its authority. ${ }^{46}$

\section{The Debs Case}

\section{The Pullman Strike Litigation}

The most important labor antitrust case during this period, United States v. Debs, ${ }^{47}$ began when the leaders of the American Railway Union disobeyed injunctions ordering them to cease conducting the Pullman strike. Their attorneys responded to the contempt proceedings that followed by questioning the jurisdiction of the courts, the validity of the injunctions, the assertion that they had been disobeyed, and so on. Although none of these arguments persuaded Judge Woods, who heard the case in the circuit court at Chicago, two of them seemed to impress him. The first raised the same question that had been the chief problem for Judge Billings in the Workingmen's Council case. How, Debs' attorneys asked, could the union be said to have violated the Sherman Act? It was not a "combination in restraint of trade"; and even supposing that its activities had injured or restrained trade, there was a vast legal difference between injuring or restraining trade and being "in restraint of trade." Woods' resolution of this difficulty, more sophisticated and complex than Billings', rested on a novel reading of the statute. The first section of the act, as Judge Woods interpreted it, defined three distinct categories: contracts in restraint of trade, combinations in restraint of trade, and conspiracies. The distinctness of the three or, more particularly, of the third in relation to the first two, was emphasized by the act's title, which stated that the act was designed to prohibit "unlawful" contracts and combinations in restraint of trade -the sort that had been considered illicit at common law. But the qualification implicit in the title obviously did not attach to conspiracies, which are by definition unlawful. The question then arose, what sort of conspiracies did the Sherman Act forbid? Not "conspirac[ies] . . . in restraint of trade," for no such category was known at common law; nor, Woods insisted, only those conspiracies involving contracts or combinations in restraint of trade. ${ }^{48}$ The answer was to be found by interpreting the phrase "conspiracy . . . in restraint of trade or commerce" as equivalent to "conspiracy to restrain trade or commerce." Since "conspiracy . . . in restraint of trade" did not, to be sure, have a well-established meaning at common law, the Woods construction did

46. See, e.g., United States v. Cassidy, 67 Fed. 698, 705 (N.D. Cal. 1895) (charge to jury) ; United States v. Elliot, 62 Fed. 801,803 (C.C.E.D. Mo. 1894); In re Grand Jury, 62 Fed. 840,841 (N.D. Cal. 1894) (charge); Thomas v. Cincinnati, N.O. \& T. P. Ry., 62 Fed. S03, 821 (C.C.S.D. Ohio 1894).

47. 64 Fed. 724 (C.C.N.D. III. 1894).

48. Id. at 748. There are, contrary to Woods' assertion, several common-law cases of conspiracy in restraint of trade. See Letwin, The English Common Law Concerning Monopolies, 21 U. CHr. L. Rev. 355, 381 (1954). 
not stretch the language of the act as radically as had Billings' manipulation of "combination ... in restraint of trade." Woods argued that "to restrain" was not more different from "in restraint of" than "drinking house" was from "tippling house," and that courts had in the past treated the latter two as synonymous. This much established, the course of his argument required him next to insist that "trade" and "commerce" were not synonyms. He had no difficulty in establishing that "commerce" as used in the Sherman Act meant "commerce" as used in the Constitution to define the regulatory power of Congress. And this completed the foundations of the principle he now announced: the Sherman Act prohibited conspiracies to injure or restrain interstate commerce. ${ }^{49}$

Having proceeded so far by reasoning from the language of the act, Woods now turned to its policy. He observed that various decisions had narrowed the scope of the statute until it apparently applied only to commodities in the course of transportation among the states, or to agreements "intended to engross or monopolize the market." He concluded that the act should be broadened by his interpretation. "Why should it not be construed to embrace all conspiracies which shall be contrived with intent, or of which the necessary or probable effect shall be, to restrain, hinder, interrupt, or destroy interstate commerce?" 50 By this process, Woods tried to reinforce Billings' test; but he apparently recognized the extreme weakness of the Workingmen's Council decision, for, although he cited it as one of the precedents establishing that a court of equity had jurisdiction over such cases, he did not mention it as an authority for his interpretation of the substance of the law. ${ }^{51}$

It still remained for Woods to dispose of another argument which the Debs attorneys advanced-perhaps to exploit a gap in Billings' opinion. They insisted that many conspiracies, even though they interfered with interstate commerce, could not reasonably be supposed to violate the Sherman Act. Taking as their text the argument advanced by the defendants in United States $v$. Patterson, Debs' counsel maintained that, if the act were interpreted as prohibiting any interference with interstate commerce, it would have to be applied - contrary to its obvious purpose-to any conspiracy to commit "an act of murder, robbery, forgery, shop-breaking, store-burning, champerty, or maintenance, which in fact has a natural, though unintended, result of interference with interstate commerce." 52 Woods dismissed this assertion by denying that members of a conspiracy to murder could be considered members of a conspiracy to restrain interstate commerce, if the restraint were an unintended consequence

49. 64 Fed. at 747-52.

50. Id. at 752 .

51. Id. at 754 .

52. Id. at 752. The words as they appear in text apparently are quoted by the court from the brief for Debs; they correspond only roughly with the words used in the brief for Patterson, United States v. Patterson, 55 Fed. 605, 632 (C.C.D. Mass. 1893). For example they do not explicitly say, as Patterson's attorney did, that in view of the decisions that would otherwise result, the act must be interpreted as requiring a specific intent to interfere with interstate commerce. 
of the murder. They would, he stated, be responsible for the murder as conspirators and for the incidental restraint as individuals. ${ }^{53}$ This principle, though it answered the defendants' objection, might have created new difficulties for Woods, since it obliged him to show that the defendants had interfered with interstate commerce directly and not merely incidentally. This problem he overcame by holding that Pullman cars were "instrumentalities of commerce," that Debs and his colleagues engaged in a conspiracy to interfere with commerce when they ordered the boycott, and that they became liable as individuals for the criminal results that ensued. Moreover, when they sought to enforce the boycott by calling a strike against railroads that continued to carry Pullman cars, "the original conspiracy against the use of Pullman cars became a conspiracy against transportation and travel by railroad."54

\section{The Debs Decision as a Precedent in Subsequent Pullman Strike Proceedings}

The theory devised by Billings and reinforced by Woods became the basis of decisions in other cases arising out of the Pullman strike. In United States v. Elliott, a circuit court in Missouri issued a preliminary injunction against officers of the union and used Billings' decision as authority for its interpretation of the Sherman Act. ${ }^{55}$ A few weeks later, in overruling the defendants' demurrer in that same case, Judge Philips explained that, in the Sherman Act, "the term 'restraint of commerce' was used in its ordinary, business understanding and acceptation"; he proceeded to give a literal definition of "restraint," and concluded that it justified the injunction. ${ }^{56}$ In Thomas v. Cincimati, N.O. \& T.P. Ry., ${ }^{57}$ a private suit turning on whether a strike leader had unlawfully interfered with a receiver appointed by the court to administer the railroad, Judge William Howard Taft held the interference unlawful on several grounds. Although he seemed to regard the Sherman Act violation as the least important of these grounds, he did not hesitate to cite the Workingmen's Council decision in support of his holding or to allude to the fact that a number of judges had followed Billings' decision in enjoining the Pullman strike."s Again, Judge Morrow, in his charge to a grand jury investigating the strikers' activities in California, cited Billings' decision which, he said, established the principle that a strike accompanied by violence and intimidation was proscribed by the Sherman Act. Morrow stressed, moreover, that the Fifth Circuit Court of Appeals had affirmed this view. ${ }^{59}$ Later, when a number of strikers were tried, Morrow instructed the jury by again referring to the Billings opinion, now further reinforced by Woods' decision in the Debs case. $^{00}$

53. 64 Fed. at 752-53.

54. Id. at 765 .

55. 62 Fed. 801, 803 (C.C.E.D. Mo. 1894).

56. United States v. Elliott, 64 Fed. 27,30 (C.C.E.D. Mo. 1894).

57. 62 Fed. 803 (C.C.S.D. Ohio 1894).

58. Id. at 821-22.

59. In re Grand Jury, 62 Fed. 840, 841-42 (N.D. Cal. 1894).

60. United States v. Cassidy, 67 Fed. 698, 705 (N.D. Cal. 1895). 
When the Debs case came before it, the Supreme Court neither endorsed nor rejected the Billings-Woods-Morrow theory of the Sherman Act. The Court based its decision instead on an argument advanced by Attorney General Olney - that the Government did not need to invoke the Sherman Act, since it had common-law authority to obtain injunctions against disturbances amounting to a public nuisance. The Court said nothing about Woods' interpretation of the act except that its silence was not to be taken to mean disagreement. ${ }^{\text {B1 }}$ Woods' literal reading of the statute therefore continued to stand as precedent for a method of interpretation that extended the scope of the act.

\section{Jurisdictional Problems and the Knight Case}

Though many congressmen had feared that the weakest point in the act would be its constitutional basis, and though its opponents had constantly urged that it was certainly unconstitutional, no court had been forced to face this issue before 1895. As yet, no judge had failed to find that the defendants before him were engaged in interstate commerce and acting so as to affect it. The mine owners in the Jellico case had traded with dealers in another state; the whisky trust had supplied out-of-state merchants; the railroads in the Trans-Missouri and Joint Traffic cases were unquestionably engaged in interstate commerce; and Debs could not deny that he had conducted a strike against interstate carriers. To be sure, in the Greene case Judge Jackson had asserted that the federal goverment lacked power to interfere with the lawful use of property by citizens of the states and corporations created by a state, ${ }^{62}$ and he had expressed some doubt as to the interstate character of the sales recounted by the indictment, ${ }^{63}$ but these views were not essential to his decision.

The sugar trust case, United States v. E. C. Knight Co. ${ }^{64}$ was the first to turn on the question of interstate commerce. The Government's attorneys had not foreseen the difficulty-understandably, since none of the previous decisions warned them. They confidently asserted that, in buying up four of its five remaining competitors, the trust had combined and conspired with the erstwhile competitors to restrain and monopolize interstate commerce. Evidently, the federal attorneys never imagined that any question could arise as to whether the trust engaged in interstate commerce. But the strategy adopted by the Government unfortunately emphasized the very aspect of the trust's activities that was not "commercial" in the constitutional sense. The chief remedy sought was cancellation of the contracts by which the trust had acquired its competitors' plants, a solution reasonable enough in the circumstances, particularly since sound reasons existed for preferring a suit in equity to a

61. In re Debs, 158 U.S. 564,600 (1895).

62. In re Greene, 52 Fed. 104, 112-13 (C.C.S.D. Ohio 1892).

63. Id. at 117 .

64. 60 Fed. 306 (C.C.E.D. Pa.), aff'd, 60 Fed. 934 (3d Cir. 1894), aff'd, 156 U.S. 1 (1895). 
criminal indictment. ${ }^{65}$ Nevertheless, the proposed remedy called attention to the trust's manufacturing activities, which necessarily went on within states rather than among states. Perhaps still more inauspicious, as it happened, was the fact that all four of the purchased plants were located in the same state and, indeed, in the same city, Philadelphia. District Judge Butler seized on this as the central fact that disposed of the entire issue. "The contracts and acts of the defendants," he held, "relate exclusively to the acquisition of sugar refineries and the business of sugar refining, in Pennsylvania. They have no reference and bear no relation to commerce between the states or with foreign nations." statute.

In the chief lines of his argument, Butler followed Judge Jackson's reasoning in the Greene case, but without fully understanding it. The essential question, Butler said, had been "fully considered" by Jackson ("now of the Supreme Court") in an opinion that was "clear and satisfactory."67 Despite its clarity, however, Butler did not quite appreciate its implications. He maintained that the sugar trust's monopoly of manufacture did not give it a monopoly of commerce because commerce was "untouched, unrestrained and open to all who choose to engage in it." 68 This was certainly Jackson's test of monopoly, but Jackson would not have made the initial concession that the trust had a monopoly of manufacture; for he would have found that the trust had done nothing to close manufacturing to any who might "choose to engage in it." Oddly enough, Butler did take the trouble of listing among the material facts proved by evidence "that the contract of sale in each instance left the sellers free to establish other refineries and continue the business if they should see fit to do so."69 Clearly, if he was using Jackson's criterion of monopoly, then this fact established that the trust had no monopoly of manufacturing; and, if he was not using Jackson's criterion, the fact was immaterial. Butler moved to more solid ground when he considered whether the trust had a secondary monopoly of commerce. He maintained that, even if it had one, the trust restrained commerce only incidentally and therefore did not violate the act, which could only prohibit "direct" interference with commerce. ${ }^{70}$ The Third Circuit Court of Appeals upheld Butler's decision and emphasized the core of the argument by insisting that "the questioned conduct of the defendants"- that is, the contracts to purchase competitors' plants-did not concern interstate commerce. ${ }^{71}$

65. The whisky trust defendants had complained that criminal action was, in effect, persecution, and District Judge Ricks, in one of the whisky trust cases, had suggested that the courts would be more receptive to civil suits, In re Corning, 51 Fed. 205, 212-13 (N.D. Ohio 1892). In any event, the settled rules of interpretation required courts to construe a criminal statute narrowly.

66. 60 Fed. at 309 .

67. Id. at 310 .

68. Id. at 309.

69. Id. at 307 .

70. Id. at 309-10.

71. United States v. E. C. Knight Co., 60 Fed. 934 (3d Cir. 1894). 
The Government's appeal in the Knight case was decided by the Supreme Court early in $1895,7^{2}$ a few months before the opinion in the Debs case was handed down. Chief Justice Fuller, in affirming the decisions of the lower courts, at the same time further clarified the central problem and disposed of the collateral issues. He began his opinion by insisting that the suit turned solely on whether the contracts to buy up competitors were valid. He then briefly dismissed each of the other questions raised by the parties and by Butler's opinion. It did not matter, he said, whether monopoly meant only a privilege granted by the state or a power acquired by the private efforts of individuals. It did not matter whether the case involved a combination, or whether Butler was correct in thinking that no combination could be shown here because the trust had made a separate bargain with each of the four competitors. Nor was it significant, as Butler thought, that the trust lowered the price of sugar, for low prices did not relieve "the objection to concentration of power." Finally-and most important in view of Butler's treatment of the case-it made no difference that the contracts were not in restraint of trade, though the Chief Justice obviously did not believe that the absence of restraint could be deduced from the fact that "others were theoretically left free to go into the business of refining sugar, and the original stockholders of the Philadelphia refineries after becoming stockholders of the American Company might go into competition with themselves, or, parting with that stock, might set up again for themselves."73

From the way Fuller disposed of the implications of Butler's "material facts," it is clear that he did not accept Jackson's theory that competition would inevitably destroy the trusts. His reference to "concentration of power," his sarcastic treatment of the possibility of new competitors entering or old competitors re-entering the industry, his refusal to distinguish between a monopoly in fact and a monopoly at law-all these indicate a sharp disapproval of the sugar trust's position and practices. Nevertheless, he insisted that the fundamental legal question was "whether conceding that the existence of a monopoly in manufacture is established by the evidence, that monopoly can be directly suppressed under the Act of Congress in the mode attempted by this bill."74 This way of putting the case stressed the two parts of the question: first, whether the Sherman Act could destroy a monopoly of manufacture, and, second, whether the attempt to dissolve the contracts involved in this case was an appropriate way to invoke this act against these defendants. Fuller answered the first half of the question by holding that the monopoly of manufacture only "incidentally and indirectly" affected commerce and that it therefore was not amenable to federal statutes based on the commerce clause. ${ }^{75}$ The second part he answered by suggesting that, had the Government concentrated its attack on the trust's commercial activities, the decision would have gone differently.

72. United States v. E. C. Knight Co., 156 U.S. 1 (1895).

73. Id. at 9-11.

74. Id. at 11 .

75. Id. at 12 . 
To assail the trust for acquiring manufacturing plants was inevitably to make the trust's commercial activities appear secondary; but if its commercial activities had been emphasized in the bill, no constitutional question could have arisen. This suggestion appears in his first summary of the case as well as in his closing remark that "there was nothing in the proofs to indicate any intention to put a restraint upon trade or commerce, and the fact, as we have seen, that trade or commerce might be indirectly affected was not enough to entitle complainants to a decree."76

Many other signs in Fuller's opinion suggest that, but for this defect in the Government's strategy, the Court would have decided in its favor. In discussing what Butler called the material facts of the case, Fuller implied that the trust really had imposed restraints on other parties, albeit hidden restraints, so that, even under Jackson's doctrine, they might have been condemned. But the Court was apparently ready to go further than Jackson in presuming that a monopoly was illegal. "[A]11 the authorities agree," Fuller wrote, "that in order to vitiate a contract or combination it is not essential that its result should be a complete monopoly; it is sufficient if it really tends to that end and to deprive the public of the advantages which flow from free competition."77 Significantly, Fuller's opinion did not approve or even mention Jackson's opinion in the Greene case. The Chief Justice's attitude throughout shows that the decision of the Court depended strictly on the facts of the case. It did not lay down the rule, often ascribed to the Knight decision, that manufacturers as such are immune from the Sherman Act, but rather held that manufacturing was immune, and therefore that manufacturers were subject to the act only in so far as their activities constituted interstate commerce or directly affected it.

Justice Harlan's dissent in the Knight case, although it denied at each critical point the conclusions of the majority, really rested on the assumption that the Court had authority to treat the case in a broader fashion than that proposed by the Government. Along with its prayer for a decree annulling the contracts of sale (and in the traditional style of bills in equity), the Government had prayed for such other relief as the Court might see fit to grant. Fuller had answered that the Court would not heed the more general prayer unless it found cause to grant the specific and principal remedy requested. Harlan, on the other hand, insisted that the general remedy could be provided even though the specific one was not. ${ }^{78}$ If one assumed, as Harlan did, that the case ought to be viewed as an attack on the sugar trust as such, rather than on the four contracts alone, the rest of Harlan's position would have been difficult to dispute. He pointed out that the sugar trust had been organized not only to manufacture sugar but also to sell it; he could quote from the district court's summary of the facts the finding that the sugar trust had bought up its competitors in order to perfect its "control over the business of refining and selling

76. Id. at 17.

77. Id. at 16.

78. Id. at $45-46$. 
sugar in this country" ${ }^{78}$ and he could insist with obvious accuracy that everyone knew the trust sold sugar throughout the country. Moreover, it was not difficult for him to show that previous decisions of the Supreme Court had held selling to be a part of commerce-indeed, the majority opinion in this very case conceded the point. The way was thus open to conclude that the trust, by its mere existence, had the power to control the sale of sugarthat is, to control part of interstate commerce-in a way forbidden by the Sherman Act. In this view of the case, the contracts to purchase the competitors were important not because they themselves violated the act but because they showed that the trust violated the act. In this manner, Harlan showed that the Court could and should have transformed the weak case brought by the Government against the contracts of sale into an overpowering case against the trust. $\mathrm{Had}$ it done so, the whole constitutional question would have disappeared. Fuller does not seem to have disagreed on this point, but he maintained, with the majority, that it was not for the Court to improve the strategy that the Government had chosen.

\section{Literal Interpretation vs. The Rule of Reason : The Trans-Missouri DECISION}

The view that the act was more than a codification of the common law, foreshadowed in the Debs and E. C. Knight decisions, achieved full expression when, in 1897, the Supreme Court reversed the lower courts in the TransMissouri Freight Association case. ${ }^{80}$ Justice Peckham took the explicit position that the Sherman Act went beyond the common law: whereas the latter proscribed only unreasonable restraints, the act in so many words prohibited every restraint. During the next six years, Peckham was the Court's chief spokesman in antitrust cases, and the doctrine he announced generally prevailed.

In the Trans-Missouri case, once it was determined that the Sherman Act applied to railroads, ${ }^{81}$ the only question was whether the Freight Association

79. Id. at 18 .

80. United States v. Trans-Missouri Freight Ass'n, 166 U.S. 290 (1897).

81. The pleadings of the Freight Association, endorsed by the decrees of the lower courts, made it imperative that Peckham first dispose of a jurisdictional question-whether the Sherman Act applied to railroads at all. The defendants had advanced a series of arguments denying that it did, chief among them the one that had prevailed below-that the Interstate Commerce Act, 24 Stat. 379 (1887), as amended, 49 U.S.C. $\$ \$ 1-27$ (1952), permitted associations like that before the Court. If the Sherman Act were presumed to prohibit the Association, they maintained, it would be construed as implicitly repealing the Interstate Commerce Act, which no one could suppose to be its purpose. Peckham, however, saw the relation between the two statutes in quite another way. He held that, although the Commerce Act did not prohibit such associations, neither did it authorize them. The Sherman Act, which did prohibit them, was therefore not in conflict with the Commerce Act, and both acts could consistently apply to railroads. United States v. Trans-Missouri Freight Ass'n, sipra note 80, at 314-16. Moreover, the Sherman Act's very language indicated that the statute reached the railroads. "When the act prohibits contracts in restraint of trade or commerce, the plain meaning of the language used includes contracts which relate to either or both subjects." Id. at 325. This was another 
violated it. The answer depended, according to the defendants, on whether the Association was illegal at common law, and they supported their view by pointing to the title of the act, which reads, "to protect trade and commerce against unlawuful restraints and monopolies." 82 But Peckham, speaking for the majority of the Court, maintained that the title did not refer to restraints and monopolies that were illegal by common-law principles but to those that were "made unlawful in the body of the statute." 83 Contracts in restraint of trade, Peckham reasoned, were a familiar category at common law, and had come to be divided into two classes. "Some of such contracts have been held void and unenforceable in the courts by reason of their restraint being unreasonable, while others have been held valid because they were not of that nature. A contract may be in restraint of trade and still be valid at common law." But the Sherman Act had erased this distinction.

When, therefore, the body of an act pronounces as illegal every contract or combination in restraint of trade or commerce among the several States, etc., the plain and ordinary meaning of such language is not limited to that kind of contract which is in unreasonable restraint of trade, but all contracts are included in such language, and no exception or limitation can be added without placing in the act that which has been omitted by Congress. ${ }^{84}$

Although the "plain language" of the act decided the issue at trial as far as he was concerned, Peckham went on to discuss the hypothetical question of whether the Association would have violated the act had the statutory prohibitions been construed as being no broader than those at the common law. The common law, he asserted, had come to tolerate contracts that included a restraint of trade collateral to the sale of a business-the sort of arrangement by which the seller of a shop might agree not to open a competing business in the same neighborhood. And then, surprisingly, Peckham added that such contracts "might not be included, within the letter or spirit of the statute."85 His next sentence explained this apparent contradiction by implying that judges may carve exceptions from the letter of the law in order to bring its effect closer to the legislators' intent. But Peckham, unlike some other judges, would not go so far as to assert that all reasonable restraints should be excepted on the same principle.

He turned now to the merits of the arguments by which the defendants tried to show that the Association constituted a reasonable restraint and was formed

way of saying what Woods had said in the Debs case: since the act, read literally, prohibited arrangements in restraint of interstate commerce, a restrictive agreement among interstate railways would certainly be within its scope. Adopting another argument advanced by Woods, Peckham maintained, moreover, that inasmuch as the Knight decision excluded manufacturing from the scope of the act, to exclude railroads as well "would leave little for the act to take effect upon." Id. at 313,326 .

82. Emphasis added.

83. Id. at 327 .

84. Id. at 328 .

85. Id. at 329 . 
to achieve purposes which Congress could not have meant to declare illegal. They urged that competition among railroads is always excessive and, if unrestrained, would lead to bankruptcy and ruin. A combination designed to prevent this result by restricting excess competition and establishing reasonable rates could not be supposed contrary to public policy. Peckham was inclined to agree that railroads always stood in danger of ruinous competition, ${ }^{80}$ but he rejoined that many commentators took the opposite view-that full competition not only benefited the public but, in the long run, did not injure the railroads. ${ }^{87}$ Morever, he asserted, it would be impossible to determine whether rates set by a combination were reasonable, and recognition of this difficulty might well have prompted Congress to prohibit all agreements in restraint of trade, whether reasonable or not. ${ }^{8 s}$ It might even be true, he conceded, that the Association was valid at common law. The argument to the contrary was "not entirely conclusive." 89 But, in any event, Congress had refused to distinguish in the body of the act between reasonable and unreasonable restraints, and the Court would decline "to read into the act by way of judicial legislation an exception that is not placed there by the law-making branch of the Government."9o Thus, every inquiry led Peckham back to the same essential rule, that the act must be given its literal meaning.

\section{Justice White's Dissent}

Peckham's opinion called forth a strong dissent, written by Justice White, which is memorable as the first statement of the doctrine later known as the rule of reason. All of the majority's errors White summarized as "unreasonable." The word runs like a refrain through his opinion. While the common law invalidated only unreasonable restraints on trade, the present agreement between the defendants was reasonable-so much, White said, was conceded by the majority. ${ }^{91}$ The contract, therefore, was reasonable according to the common law, or, as White put it, according to "general principles of law." But the act, as Peckham construed it, condemned the contract. In other words, it condemned a reasonable contract. Therefore, White concluded, the act must be unreasonable. If so, Congress was unreasonable in passing it, and the courts could not avail themselves of reason in interpreting it. ${ }^{92}$ Having shown this logical difficulty in Peckham's opinion, White moved on to an argument from precedent. Was it true, as Peckham asserted, that the common law considered any contract that restrained trade a "contract in restraint of trade"? Could a

86. Id. at 331,340 .

87. Id. at 338 .

88. Id. at 331-32.

89. Id. at 335 .

90. Id. at 340 .

91. Id. at 343-44. This was a slight exaggeration; the majority conceded the point about the common law, but merely assumed for the sake of argument that the agreement was reasonable. Id. at 335 .

92. Id. at 344 . 
"contract in restraint of trade," as Peckham asserted, be either valid or invalid at common law? White answered no. He maintained that the term "contract in restraint of trade" had always been reserved for illegal contracts and had never been used, except in a loose and imprecise way, to describe permissible agreements. Only those contracts that unreasonably restrained trade were illegal and properly known as "contracts in restraint of trade." The source of confusion, White explained, was that, originally, every contract which restrained trade had been interpreted by the courts as a "contract in restraint of trade," that is, as an illegal contract. But, in time, more and more contracts that restrained trade were judged by the courts to restrain it "reasonably," and these contracts were therefore excluded from the proscribed class of "contracts in restraint of trade." 93 It followed that the Sherman Act, in prohibiting "every contract in restraint of trade," did not prohibit every contract tending to restrain trade but only those agreements which restrained it unreasonably and which had been prohibited at common law as "contracts in restraint of trade."

Having stated his chief objection to the majority's interpretation and presented his own view of the act, White added some reflections on the impolicy of the majority position. For one thing, he pointed out, a rigorous application of Peckham's rule would render illegal every contract in restraint of trade which was collateral to a sale of property. Peckham was inconsistent in holding first that "every" meant what it said and then that collateral restraints might be permissible. But if "every" were taken as all-inclusive and "contract in restraint of trade" were regarded as describing any contract that in fact restrained trade, then the act would prohibit trade-or at least that part of trade comprising sales of property to which restraining conditions were attached. The result would be that a statute designed to free trade would, unreasonably, be enforced so as to restrain it. Nor was this the most dire result he foresaw. By denying the rule of reason and destroying the security afforded by the rule's flexibility, Peckham's interpretation would subject liberty of contract and freedom of trade "to the mere caprice of judicial authority."94 $\mathrm{He}$ offered little hope that the fabric of civil society could be preserved unless the courts returned to the rule of reason and interpreted the Sherman Act as prohibiting only unreasonable restraints of trade.

It may seem curious that the same case should have evoked these two extreme principles of interpretation. The appearance of these divergent opinions at this moment depended to some extent on the coincidence that Peckham and White were members of the Court at the same time. But it also reflected a more permanent division of ideas in the Court, a disagreement which had probably existed before 1897 but had never before had occasion to be expressed. Since the Knight decision had gone off on a constitutional issue and the Debs case on general principles of common law and equity, the Trans-Missouri case was the first in which the Supreme Court was called on to interpret the sub-

93. Id. at $346-52$.

94. Id. at 355 . 
stance of the act. The split might have been expected, because the ambiguity of the act allowed interpretation to vary according to the diverse views that Justices entertained about the meaning of the common law and its relation to the statute. But, for the moment, and indeed for over a decade, the majority of the Court preferred Peckham's approach to the rule of reason.

\section{The Common Law Reconsmered: Taft's Addyston Pipe Decision}

Just at this moment, when the courts seemed to have settled on a literal interpretation of the Sherman Act, a decision was rendered which suggested a way to view the common law so as to give the act an almost identical interpretation. This analysis appeared in the opinion that William Howard Taft, then sitting on the Sixth Circuit Court of Appeals, wrote in the Addyston Pipe case. ${ }^{95}$

The case had been heard by the trial court in 1897,96 just a month before the Trans-Missouri decision, and had been decided-for the defendantsaccording to the prevailing doctrines. It involved six cast-iron pipe manufacturers, producing between one-fifth and one-third of the nation's supply, ${ }^{07}$ who had organized an association and a complex pooling system. When large users of pipe, chiefly municipalities and utility companies, advertised for bids, the association's executive committee would decide on the price to be asked and would award the privilege of bidding to whichever of the six member companies offered to pay the highest bonus into the association's treasury. The firm winning the right to bid was "protected" by its fellow members, who, for the sake of appearance, submitted bids slightly higher than its own. This system, which prevailed on large, special orders, was augmented by the requirement that members pay fixed bonuses on goods sold in the ordinary course of business, as well as on all sales in "reserved cities"-places assigned to each company as its exclusive market. Bonuses were not due, however, on goods sold in "free territory," the twelve New England and Middle Atlantic states where the association faced intense competition. Accumulated bonuses were periodically distributed among the members according to predetermined proportions. The Government contended and proved to the satisfaction of the trial court that the purpose of the arrangement was to reduce competition among the defendants and permit them to raise the price of pipe. The trial court held, nevertheless, that the association had not violated the Sherman Act.

The primary basis of the trial court's decision was that, since the defendants were manufacturers who affected interstate commerce only indirectly, they

95. United States v. Addyston Pipe \& Steel Co., 85 Fed. 271 (6th Cir. 1898), aff'd, 175 U.S. 211 (1899), reversing 78 Fed. 712 (C.C.E.D. Tenn. 1897).

96. United States v. Addyston Pipe \& Steel Co., 78 Fed. 712 (C.C.E.D. Tenn. 1897).

97. Id. at 714. The six firms had a total daily capacity of 650 tons, while two groups of unassociated competitors had capacities of 835 and 1550 tons daily. According to Taft, the Association had nearer one-third of the national capacity. United States v. Addyston Pipe \& Steel Co., 85 Fed. 271, 277 (6th Cir. 1898). 
were exempt from the Sherman Act under the rule of the Knight case. The lower court implied, moreover, that even if it had considered the act applicable, it would have found the association lawful. The judges attached considerable weight to affidavits presented by the defendants' customers in which the customers expressed satisfaction with the prices they had been charged. The lower court was convinced that the defendants had not been able to "raise or maintain prices above what is reasonable" 98 or, rather, that "in some instances prices have been above what was probably fair or reasonable, but the proof fails to show that the average prices have been so."99 All of which meant that, the Kuight principle aside, a combination to set reasonable prices was reasonable at common law and therefore legal under the Sherman Act.

By the time the Addyston case came up on appeal the Supreme Court had handed down the Trans-Missouri decision, which undermined the position that the pipe dealers' combination was lawful because its prices were reasonable. In reversing the lower court in the Addyston case, however, the circuit court of appeals did not rely very heavily on Peckham's reasoning. To be sure, Taft did open his opinion by questioning the defendants' assertion that they had not violated the act because they had done nothing contrary to common law. "It might be a sufficient answer to this contention," he wrote, "to point to the decision of the supreme court of the United States in U.S. v. Trans-Missouri Freight Ass'n ... in which it was held that contracts in restraint of interstate transportation were within the statute, whether the restraints would be regarded as reasonable at common law or not."100 But the way Taft phrased Peckham's decision shows that he was uncertain about its application. He said it "might be," not that it definitely was, a "sufficient answer"; he represented the rule of the Trans-Missouri case as applying to "transportation" rather than to the broader subject, "commerce"; and he thought that some merit might be due the suggestion that Peckham's decision was more stringent because the defendants were quasi-public corporations than it would have been had ordinary private companies been involved.

Taft preferred to rest the decision on other grounds. An examination of the common law convinced him, as it had Peckham, that "collateral" or "ancillary" restraints of trade were valid. According to Peckham, this was a ground for excepting them from the general operation of the Sherman Act as literally interpreted. But Taft emphasized the obverse-that all nonancillary restraints were void at common law-and in effect concluded that the Sherman Act need not be thought to go beyond the common law to be given an interpretation as broad as Peckham's.

He therefore devoted the core of his opinion to showing that an agreement like that among the pipe manufacturers was invalid at common law. His review of the precedents began with White's historical generalization: in the begin-

98. 78 Fed. at 714.

99. Id. at 715 .

100. 85 Fed. at 278. 
ning the common law prohibited all restraints of trade; later, becoming more flexible, it permitted some. But, Taft said-and here he diverged from the usual analysis-the exceptions to the rule were all of one sort. They involved contracts in which the restraint was ancillary to some other main object, such as the sale of a business or property, the founding or dissolution of a partnership, or the employment of an apprentice or agent. Such contracts had been upheld when they were reasonable, "reasonableness" being measured in relation to the legitimate object of the contract; so that a restraint attached to the sale of a business, for instance, would be regarded as reasonable, and unexceptionable, if it offered the buyer only as much protection as was necessary to preserve the goodwill of the business. ${ }^{101}$ Taft's interpretation of the cases implied (contrary to the views of many commentators and especially of English judges) that the common law had not withdrawn its favor from free competition in order to bestow it upon free contract, but had instead promoted the "free purchase and sale of property" while defending with undiminished zeal the freedom to compete. For, Taft maintained, reasonable ancillary restraints did nothing to diminish competition; a buyer who undertook to observe such a restraint "was not reducing competition, but was only securing the seller against an increase of competition of his own creating." 102

His view was supported, Taft said, by the fact that the common law regularly invalidated the other category of contracts in restraint of trade, those "where the sole object of the parties . . . is merely to restrain competition."103 The restraints imposed by such contracts could not be reasonable because these contracts had no lawful main purpose to justify the restraint or to serve as a measure of its reasonableness. If courts undertook to distinguish among them, the only standard they could apply would be "the vague and varying opinion of judges as to how much, on principles of political economy, men ought to be allowed to restrain competition." 104 The fact nevertheless remained that, in a few cases, some courts had sanctioned nonancillary contracts in restraint of trade, and Taft now proceeded to show that, in assuming "the power to say ... how much restraint of competition is in the public interest," these courts had mistaken the common-law rules and "set sail on a sea of doubt."105

Of the precedents that the defendants in this case and judges in previous antitrust cases had relied on as authoritative, but that Taft believed erroneous, he first considered Wickens $v$. Evans. ${ }^{106}$ There, the court had approved an agreement among three trunk makers to partition England into districts in which each would be the exclusive supplier. The court reasoned that the restraint left the trade open to entry by all other persons. The principle of the decision was the same which Jackson had espoused in the Greene case, and

101. Id. at 280-82.

102. Id. at 281 .

103. Id. at 282 .

104. Id. at 283 .

105. Id. at 284 .

106. 3 Y. \& J. 318, 148 Eng. Rep. 1201 (Ex. 1829). 
perhaps Taft regarded this as an additional reason for refuting an argument that would, he said, "validate the most complete local monopoly of the present day."107 Not that he denied competition would sooner or later prevail over monopolies, but he insisted that the law could not idly wait for the eventual outcome.

It may be, as suggested by the court, that local monopolies cannot endure long, because their very existence tempts outside capital into competition; but the public policy embodied in the common law requires the discouragement of monopolies, however temporary their existence may be. The public interest may suffer severely while new competition is slowly developing. ${ }^{108}$

In any event, he added, the decision in Wickens v. Evans could not be reconciled with later cases, English as well as American.

Similar reasons prevailed against the other precedents that were supposed to show that the common law approved as reasonable some outright restraints of trade. ${ }^{100}$ An English decision, upholding a combination among stevedore companies, was refuted by an American case suppressing a similar combination. A Canadian decision favoring a combination of salt manufacturers was outweighed by the contrary decision of an Ohio court. A Wisconsin decision was dismissed on account of its age. And a New York decision was disqualified because, resting on the principle "that competition is not invariably a public benefaction," 110 it wrongly left the court discretion to decide how much competition was beneficent. It also diametrically opposed a Kentucky decision.

The Mogul Steamship case, Taft insisted, did not properly belong among the other seemingly contrary decisions, although the defendants sought to place it there. The courts, he said, had not upheld the legality of the steamship combination in that case; they had held that it did not illegally damage its competitors. Furthermore, several of the judges had said that they would have refused to enforce the agreement if the case had come up on that issue. The Mogul decision, therefore, like all the decisions except those few in which judges had mistakenly strayed, supported the proposition that any agreement made for the sole purpose of restricting competition was illegal at common law. And if the Sherman Act followed the common law, it too condemned all such agreements-all unreasonable ancillary restraints and all direct restraints whatsoever, or, in other words, all unreasonable contracts in restraint of trade and all combinations in restraint of trade.

Once the decision was grounded on the illegality of all restraints except ancillary restraints, many of the defendants' arguments became irrelevant. In particular, their plea that the pipe manufacturers' combination must be deemed reasonable because it charged reasonable prices, and the affidavits to that

107. 85 Fed. at 284 .

108. Ibid.

109. Id. at 284-87.

110. Id. at 286 . 
effect, were of no avail; for Taft held that, by forming the association, they had acquired the power to charge unreasonable prices, whether or not they had thus far chosen to exercise it. But, Taft added, "if it were important, we should unhesitatingly find that the prices charged in the instances which were in evidence were unreasonable"; they were far above the cost of production and transportation plus a reasonable profit.111

The question yet remained whether this combination, illegal at common law, was constitutionally subject to the Sherman Act. The defendants strongly urged that it was not, maintaining that, as pipe manufacturers, they much more nearly resembled the sugar refiners of the Knight case than the railroads in the Trans-Missouri case. Taft flatly rejected this argument. The Knight case, he held, had been decided for the defendants because the contracts in question "related only to the manufacture of refined sugar, and not to its sale throughout the country." ${ }^{12}$ The Supreme Court had not meant that any contract between manufacturers was immune, but only such contracts as related exclusively to manufacturing. "The obstacle in the way of granting the relief asked in U.S. v. E. C. Knight Co. was (to use the language of the chief justice) that 'the contracts and acts of the defendant related exclusively to the acquisition of the Philadelphia refineries, and the business of sugar refining in Pennsylvania, and bore no direct relation to commerce between the states or with foreign nations.' "113 The contracts in this case were of a quite different sort. They concerned the sale in one state of goods to be delivered in another, and were "interstate commerce in its strictest and highest sense", $; 14$ indeed, they were of the exact kind that Chief Justice Fuller had designated as most certainly subject to federal regulation, "contracts to buy, sell, or exchange goods to be transported among the several states."115 No doubt existed, then, that the defendants had violated the Sherman Act.

Taft's pruning operation cut away the irregular branches of the common law and showed that its outlines were very similar to those which Peckham attributed to the statute. Meanwhile, however, the Supreme Court persisted in Peckham's analysis of the act.

\section{The Final Cases of the Decade}

During 1898 and 1899, Justice Peckham had the opportunity to restate his doctrine in four more antitrust opinions. In each of these, though he continued to maintain that the act went beyond the common law, he retreated from the extreme position he had taken in the Trans-Missouri case by clarifying his definition of "restraint of trade."

111. Id. at 293.

112. Id. at 296 .

113. Id. at 298.

114. Id. at 295 .

115. Id. at 297 . 
The severity of the Trans-Missouri rule came under serious question in United States v. Joint Traffic Association, ${ }^{116}$ the first of this group of cases. The defendants argued that if Peckham's interpretation were to prevail, the act would prohibit a great variety of contracts in restraint of trade that were admittedly necessary and beneficial. This result, defendants urged, would unconstitutionally interfere with freedom of contract. In short, either Peckham's interpretation was erroneous or the act was unconstitutional. They listed, as among these useful and commendable contracts or combinations in restraint of trade, labor unions, partnerships or corporations formed by persons already engaged in the same business, common selling agencies, an agreement by which the vendor of a business promised not to compete, and a covenant restricting the use of real estate. To this, Peckham answered, first, that as none of the contracts listed was like the defendants' association, their argument was somewhat beside the point. Moreover, he went on to say, the argument was not well founded. For instance, the formation of partnerships and corporations had "never, to our knowledge, been regarded in the nature of a contract in restraint of trade or commerce."117 It seems odd that Peckham should have made this appeal to precedent when he explicitly denied that the common law was an appropriate basis for interpreting the act; this and similar passages show, however, that he did sometimes invoke common law as a guide to the meaning of "restraint of trade." Characteristically, he found guidance in a more literal reading of the statute a moment later when he said, "It might also be difficult to show that the appointment by two or more producers of the same person to sell their goods on commission was a matter in any degree in restraint of trade." This statement implicitly reasserted that the proper method to determine whether a contract restrained trade was not to refer to the common law but rather to decide by a process of reasoning whether a practice actually restricted the exchange or movement of goods. Later on, Peckham did outline the nature of restraints, but for the present he was content to continue his refutation of the argument that the act, under his interpretation, would prohibit desirable restraints. Taking up another of the defendants' examples, he pointed out that the sale of a business with a collateral covenant not to compete was permissible; this type of contract had been explicitly discussed in the Trans-Missouri opinion and described there as outside the spirit of the act. ${ }^{118}$

Having given particular reasons why some contracts were not within the statutory proscription, he now turned to the general principle which assured that his interpretation would not render illegal all sorts of other indispensable and beneficial contracts and combinations. The principle, discussed at length in another antitrust opinion delivered on the same day, Hopkins $v$. United States, ${ }^{110}$ was a slightly modified version of the rule which governed the

116. 171 U.S. 505 (1898).

117. Id. at $56 \%$.

118. Id. at 568 .

119. 171 U.S. 578 (1898). 
Knight case: Peckham held that the act applied only to contracts "whose direct and immediate effect" was to restrain interstate commerce. This meant, he said, that "an agreement entered into for the purpose of promoting the legitimate business of an individual or corporation, with no purpose to thereby affect or restrain interstate commerce, and which does not directly restrain such commerce, is not, as we think, covered by the act." 120 The act was still to be interpreted without reference to common law, but the literal reading would henceforth be moderated by interpreting "restraint" as "direct and immediate restraint." In this way, Peckham was using a constitutional criterion to do the same work accomplished by the common-law distinction between reasonable and unreasonable restraints. A restraint attached to a sale of property would be lawful under the act, according to Taft, because it was reasonable and ancillary at common law, and, according to Peckham, because it had no direct or immediate effect on commerce. A restraint imposed by a combination of pipe manufacturers was prohibited by the act, in Taft's view, because it was not ancillary, and therefore not valid at common law, and, in Peckham's opinion, because it directly and immediately affected commerce. Although the content of the rules was different, they might often, and usually did, lead to the same conclusions. The extent of Peckham's retreat from the extreme position of the Trans-Missouri opinion is shown by a passage in the Hopkins decision, which Peckham considered so important that he quoted it in the Joint Traffic opinion: "The act of Congress must have a reasonable construction or else there would scarcely be an agreement or contract among businessmen that could not be said to have, indirectly or remotely, some bearing upon interstate commerce, and possibly to restrain it."121

The opinions written by Peckham in the Supreme Court's last four antitrust cases of the century-Joint Traffic, Hopkins, Anderson, and Addyston Pipe-provided a clearer view of how he determined whether an agreement "directly and immediately" restrained commerce. To interpret restraint of commerce quite literally, as any reduction in the physical quantity of goods moving among the states, might lead to ludicrous results. A shipowner who scrapped a ship, a manufacturer who closed his plant, a laborer who retiredall of these and many more would appear to have violated the act. Peckham therefore asked whether the combination complained of actually reduced competition and thus tended toward monopoly. The Joint Traffic Association was condemned for this reason. "An agreement of the nature of this one which directly and effectually stifles competition, must be regarded under the statute as one in restraint of trade." ${ }^{22}$ The association in the Anderson case did not reduce competition and, hence, was lawful. ${ }^{123}$ The Addyston Pipe

120. 171 U.S. at 568.

121. Hopkins v. United States, 171 U.S. 578, 600 (1898), quoted in 171 U.S. at 568.

122. 171 U.S. at 577.

123. Anderson v. United States, 171 U.S. 604, 614 (1898). 
combination, like that in the Joint Traffic case, was unlawful, however, and Peckham once again stated the rule:

We have no doubt that where the direct and immediate effect of a contract or combination among particular dealers in a commodity is to destroy competition between them and others, so that the parties to the contract or combination may obtain increased prices for themselves, such contract or combination amounts to a restraint of trade in the commodity, even though contracts to buy sucl commodity at the enhanced price are continually being made. ${ }^{124}$

Although Peckham had begun by insisting that the act meant what its plain language said, the necessity of applying the statute to concrete situations had forced him to interpret the plain words. Constitutional considerations and reflection on the legislative intent suggested the proper interpretation, and he now understood "every contract in restraint of trade or commerce among the states" to mean in effect "every contract that directly and immediately restricts competition and directly affects commerce among the states." It was this formula which in the main controlled the interpretation of antitrust cases for the following decade.

124. Addyston Pipe \& Steel Co. v. United States, 175 U.S. 211, 244 (1899). 


\section{THE YALE LAW JOURNAL}

\begin{tabular}{lll}
\hline Volume 68 & APRIL 1959 & NuMIRer 5 \\
\hline
\end{tabular}

Mitchez J. Ezer

BURT W. GRIFFIN

Jerold H. IsRael

Michaec J. Nassau

ALAN I. WURTZEL

Note and Comment

Editors

Sydney M. Cone, III

Editor-in-Chief ROBERT J. ENGELMAN

JOHN K. MCNULTY

Article and Book

Review Editors

T. Cecil Wray, JR.

Managing Editor

Matrhew T. Adams

David Albenda

Alan Appetibaum

ROBERT L. BARD

Arthur J. Berk

Norman A. Bikales

BENJAMIN W. Boley

Richard A. Brady

Peter D. Caldwell

Jadies M. Edwards

ErIEzer EretI

David R. Evans

J. Edward Fowler

Thomas N. Frohock

David Goldberg

Stuart B. Goldman
RICHARD S. HARRISON

NEIL S. HECHT

REUBEN L. HEDLUNd

JACOB W. HeLler

Alan M. Hoffaran

Benjamin T. Hopkins, II

JaMres M. JoHNSTONE

WiLliam A. Kass

N. HERSCHEL KOBLENZ

EUgene I. LAMBberT

J. D. LAMrberT

IRVING I. LesNick

JoHN C. MCGUire

Frederick W. MCNABB, JR.

Stephen ManN
Donald G. Marshall

BRUCE Montgonery

SAMIUEL MYERS

J. Alexander Onderdonk

Alan D. Pekelner

Charles J. Prentiss

HERBERT SCHREIBER

BarRy SidMaN

Richard Lauder Sutton

Colin C. TaIt

JoHN W. VANDOREN

GILBert PaUL Verbit

HERBERT S. Wander

Donald P. Wefer

Patricia W. Weingerg

ROBERT L. WeINBERG
Marie McMahoN

Business Secretary
Datid BerLiner

Business Manager

\section{CONTRIBUTORS TO THIS ISSUE}

Winliami D. Warken. A.B. 1948, J.D. 1950, University of Illinois; J.S.D. 1957, Yale University. Professor of Law, University of Illinois.

Harold D. LAssweld. Ph.B. 1922, University of Chicago. Graduate study at Universities of Geneva, Paris, London, Berlin. Ph.D 1926, University of Chicago. Washington School of Psychiatry, 1938-1939. Fellow, Center for Advanced Study in the Behavioral Sciences. Professor of Law and Political Science, Yale University.

Richard C. Donnelly. Ph.B. 1936, Washburn College; LL.B. 1938, Washburn Municipal University; J.S.D. 1949, Yale Law School. Member of the Kansas and Connecticut Bars. Member, Connecticut State Board of Parole. Professor of Law, Yale University.

Wirliam Letwin. B.A. 1943, Ph.D. 1951, University of Chicago. Post-doctoral Fellow, Economics Department, University of Chicago, 1951-1952. Research Assistant, University of Chicago Law School, 1953-1955. Associate Professor of Industrial History, School of Industrial Management, Massachusetts Institute of Technology. 